\title{
Decision Model for the Media Selection
}

\author{
UDK: 659.4
}

Tatjana Kozjek

University of Ljubliana, Faculty of Administration

tatjana.kozjek@fu.uni-li.si

Vladislav Rajkovič

University of Maribor, Faculty of Organizational Sciences

vladislav.rajkovic@fov.uni-mb.si

Marko Ferjan

University of Maribor, Faculty of Organizational Sciences

marko.ferjan@fov.uni-mb.si

\section{ABSTRACT}

The article presents the decision model for choosing the media in the performance of public relations (PR). The core of the model lies in the use of modern information methods with the accent on the artificial intelligence methods in decision-making processes which allow transparency and simple explanation of the decision knowledge and of the decision itself. The framework of the solution is the description of the realization of the model with the support of the DEXi system. The model covers the qualitative and the quantitative measures for the final choice. This allows a more wholesome overview of the media and of the goals the decision aims to achieve. The determined fundamental elements of the model are: the target public, the goals the organization aims to achieve via public relations, the resources assigned to the public relations, the messages to transmit to the public, etc. The criteria which form constituent parts of the decision model have been designed on the basis of public relations literature study and the practical experience of the Faculty.

Key words: public relations, choice of media, multi-attribute decisionmaking, decision models, DEXi

JEL: C30, 033, M30

Kozjek, T., Rajkovič, V. \& Ferjan, M. (2012).

Decision Model for the Media Selection. Uprava X(1), 145-165. 


\section{Introduction}

The process of communication is one of the most crucial processes in human interaction and creativity. Communication is extremely vital for everyday social and economic life. An organization cannot function normally without communication, because of its enormous impact on relations among all parties within the organization who aim to manage the work process successfully and achieve common goals.

The article presents the decision model for the choice of the media in public relations in the case of the faculty. Methodological research has been divided into two parts; with the aim of creating a decision model for the media selection, first, literature and sources related to public relations and decision-making were studied. The approach to the solution of the problem on the choice of the media for the execution of public relations in the article has been based on multi-attributive decision making in expert systems. The basic principle of the multi-attribute decision making methods is the decomposition of the decision problem onto smaller, less complex problems, which allow transparency and comprehension of the decision problem, and simultaneously allow making of a quality and explainable decision (Bohanec \& Rajkovič, 1999; Klein \& Methlie, 1995). The model is designed with the support of the DEXi system.

\section{Public relations}

When speaking about an organization's environment, we must first define the concept of "the public" in the context of how it is addressed in the article. The public are a group of people, who have a potential or realistic impact on the goals of an organization (Hunt \& Gruning, 1994). As Hunt and Gruning state, organizations communicate within themselves and also with others in the environment because they do not exist in isolation. Organizations thus communicate with communities, governments, customers, financial institutions and others that have relationships with them. On the other hand, factors in the environment (governments, communities, the public, etc.) may also have some kind of interest in the organization and thus communicate with it (Hunt \& Gruning, 1995, p. 5).

During almost three millennia, but essentially during the last three centuries, research on public/ness developed five basic semantic dimensions of the general concept (Splichal, 1999, p. 6): 
- "public" as a specific social category or collectivity that appears as a social actor or agent, particularly in relation to some important social issues;

- "public" as the specific nature of a particular activity or space (for example public schools);

- publicity as the "incarnation" of publicness embedded in a principle or norm, and as a universal human right, thus representing the foundations of public opinion and the doctrine of sovereignty;

- public sphere as a specific sphere;

- public opinion.

For some time organizations have become aware of the power of public opinion and many have been in fear of an unfriendly environment. As described by Tedlow (1979, p. 5), the great 19th-century American industrialist William Vanderbilt (1825-1885) was said to have exclaimed in 1882: "The public be damned!« For this reason, organizations have long tried to cultivate a good image, especially among the general public.

Sources state multiple definitions of the expression "public relations". On its 1978 global assembly, the international public relations association (IPRA) chose the following definition: public relations are a skill and a social science on analyzing trends, forecasting their consequences, on consultations to leaders of organizations and on the execution of planned programs of actions in the mutual interest of organizations and the public (Wilcox et al., 1992). Hunt and Gruning (1994) state that public relations are a formal path on which organizations communicate with the public. Kitchen (1997) claims that public relations are one of the functions of management; they cover a broad spectrum of activities and intentions in practice; they are two-way and mutual; they show that the public is not homogenous in relations to organizations, it is manifold; public relations are long rather than short-term. Kotler (2003) states that public relations represent the organization's construction of good relations with various publics with intention to create good reputation; they are a construct of a wholesome positive representation or image of the organization; they are a tool with which we put away negative rumors on various events. 
Theory classifies four basic models which organizations use to perform public relations:

- press agentry/publicity model;

- public information model;

- one-way asymmetrical model;

- two-way symmetrical model (Hunt\&Gruning, 1994).

All public relations activities must be planned, managed and evaluated. The planning is particularly important when it is to be followed by realization. The most typical ways of communication with public are:

- an event (unique, should attract attention);

- a campaign, a process consisting of various events, which may not be interconnected. The campaign can last for a longer period of time: i.e. a couple of weeks or even months. The key to understanding the campaign is, that the campaign is always concluded with a decisive event (for example: elections, voting etc.). The goal of a campaign is to achieve actions performed in the desired way (for example: favorable outcome of the election).

- a program, similar to the campaign in being comprised of a number of events, which are not necessarily interconnected, differing from a campaign in the fact that it does not have a concrete desired outcome (Hunt \& Gruning, 1994).

For the public relations it is crucial that the organization management participates. This means that the goals of public relations must be precisely defined; so must be the actual tasks, careful planning of activities, the organizational structure which allows the achievement of goals, the control functions must also be set up, and the results must be evaluated. The same goes for content, methods and the dynamics of the performance, which, if necessary, should be adjusted to the given circumstances. Public relations can be used to help increase visibility of a product, person, location, idea, activity, organization or a nation (Kotler \& Armstrong, 2006). Communications are the basic frame (Hunt \& Gruning, 1994); the essence is in the decision-making.

\section{Decision-making}

Making decisions is an activity performed daily, however not all decisions are equally important or equally difficult. Decision making is a process 
in which we choose from a number of possibilities the one which is the most suitable for our goals or demands. Computer support can essentially improve the decision-making process, because it points out the appropriate decision making processes, increases the comprehension of the problem and improves the quality of the final decision.

Decision-making is usually a part of the general problem solving and a crucial mental activity on all levels of human activities. The difficulty of decision problems varies considerably. It stretches from simple personal decisions, which are usually routine decisions we are not normally aware of, to complex problems of group decisions, in areas such as leadership, managing and planning in an enterprise, in human resource decisions, medical diagnostics and many other areas. The most common problems which arise from deciding on a medium in our case arise from: a large number of factors, which influence the decision, a large number or insufficiently defined or known possibilities, difficult recognition of the decision problems and of the goals of the decision.

The decisive process contains the following elements (Rajkovič and al., 1999):

- mass variables A: $a_{1}, a_{2}, a_{3}, \ldots, a_{m}, \ldots$;

- preferential relation $P$, which arranges group $A$ according to desirability, suitability i.e. usefulness $v(a)$, which measures the rate of the desirability $a$ in a way that for each pair $a, b$ out of $A$ there is $\mathrm{a} P \mathrm{~b} \leftrightarrow \mathrm{v}(\mathrm{a})>\mathrm{v}(\mathrm{b})$;

- the rational decision, which stands for the choice of the most desirable variable $a$; out of $A: v\left(a_{i}\right)=\max (v(a): a \in A)$.

In multi-parametric decision making there is a group of parameters $X: x_{1}, x_{2}, \ldots, x_{n}$, where $x_{i}: A \rightarrow D_{i}$, and $D_{i}$ are the stock of value for the parameter $x_{i}$. The variables are described with the vector of value $v^{*}: D_{1} \times D_{2} \times \ldots \times D_{n} \rightarrow D$. The function of utility: $A \rightarrow D$ is replaced with $v^{*}: D_{1} X k D_{2} X \rightarrow D$, where we suppose: $v\left(a_{i}\right)=v^{*}\left(x_{1}(a), x_{2}(a), x_{3}(a), \ldots, x_{n}(a)\right)$. The utility function represents the joint measurement according to all the parameters. It is a criterion function with which we determine the utility of variables on the basis of criteria and their interconnection. 


\section{Figure 1: Multi-attribute decision model}

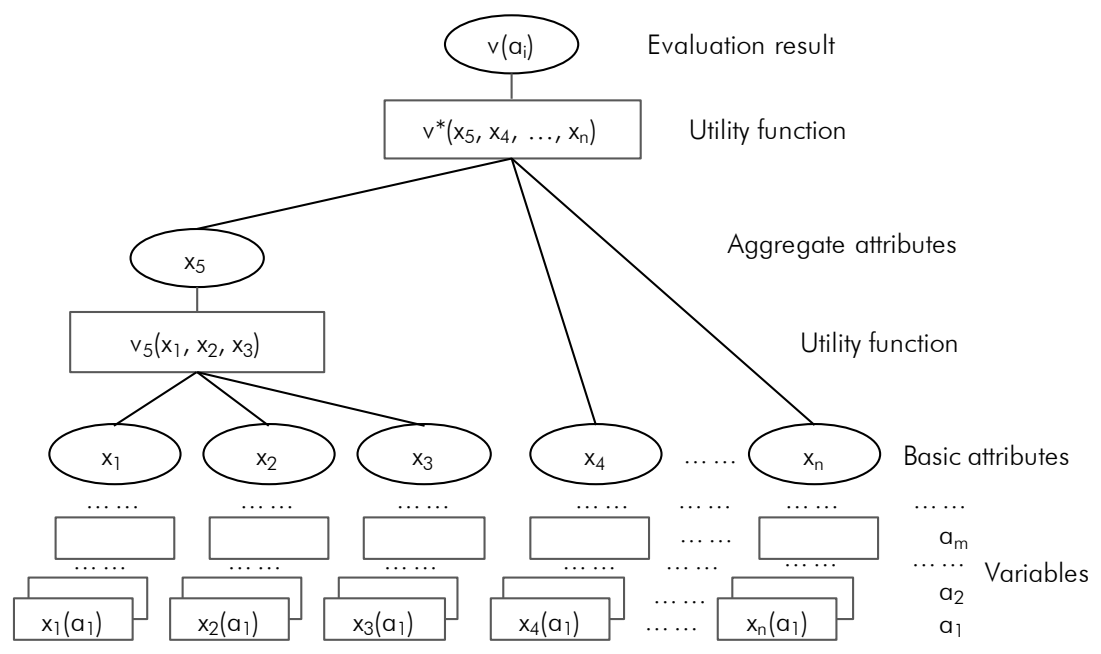

Source: taken from Bohanec \& Rajkovič (1999)

The multi-attribute decision model generally consists of two types of components: the attributes $\left(X_{i}\right)$ and the functions of utility $\left(F_{i}\right)$. Attributes, also known as parameters and criteria, are variables which stand for subproblems of the decision model. They are arranged in a hierarchical structure, which represents the mutual dependence among the attributes: high-level attributes depend on their immediate descendants. According to the position the attributes are classified between the basic attributes (terminal nodes of the tree) and the aggregate (internal nodes) attributes. Within the model each aggregate attribute has a function of utility $F$, which determines the dependence of the attribute of the immediate descendant in the structure. The options are described with the values of the basic attributes $\left(a_{i}\right)$. Evaluation of variations is running from the bottom up, i.e. with the gradual joining of values in accordance with the model structure and the functions of utility (Bohanec et al., 2000; Bohanec \& Rajkovič, 1999).

A number of disciplines in various scientific fields i.e. philosophy, psychology, economy, mathematics, decision theory, decision analysis deal with decision making problems. There is a trend of research in the field of the method of choice (Anderson \& Goltsi, 2006). The question on how to facilitate the decision maker in order to make the decision more systematic, better organized and how to facilitate the journey towards the most qualitative decision is becoming increasingly important. The decision 
making support is a wide discipline, which deals with supporting people in the decision making process. It is a part of the decision sciences that also comprise normative and descriptive approaches to decision making (Clement, 1996). It contains a number of disciplines, such as operation research, decision analyiss, decision support systems, group decision support (Mallach, 2000; Triantphyllou, 2000).

A number of methods and computer programs have been developed in order to facilitate the decision making (i.e. decision support systems). Methods of multi-attribute decision making have a solid theory base within the framework of the decision theory and the theory of utility on one side, and a successful practical use in supporting demanding decision making processes on the other side. The theory of multi-attribute decision making offers a formal base for the development of the model, where the key criterion remains the joining of evaluations of individual parameters into one complex evaluation (Bohanec \& Rajkovič, 1999; Chankong \& Haimes, 1983; Klein \& Methlie, 1995). All the options need to be decomposed into individual criteria (criteria, attributes) and separately evaluated on the basis of each parameter. The final evaluation of the variation is achieved via association. The volume of the evaluation derived from such a process is the basis for the choice of the most appropriate option (Rajkovič et al., 1999).

\section{Use of the DEXi system in choosing the public relations media}

In the article the approach to the solution of the problem on the choice of the media for public relations is based on multi-attributive decision making in expert systems. As already mentioned, the basic principle of the multi-attribute decision making methods is the decomposition of the decision problem onto smaller, less complex problems, allowing transparency and comprehension of the decision problem, and simultaneously making a quality and explainable decision. The model is designed with the support of the DEXi system, because it inables modeling and it is user-friendly. The formation of the decisive model was based on the following phases: problem identification, criteria identification, definition of utility functions, and description of options, evaluation and analysis of the options.

In this chapter, the prototype of the decision model for the choice of the medium for the Faculty's public relations is presented. The decision model 
is the basis for the decision on the media, which the Faculty is to use for its public relations.

The criteria vital for the planning and realization of the public relations program are the basis of the decision model and were designed after a careful study of the existing expert literature and the current state of affairs in the field of public relations at the Faculty. The DEXi system is used for the execution; the software follows the concept of multi-parameter evaluation as it decomposes the basic problem onto smaller, less complex sub-problems. The evaluation of the option is calculated with the processes of association of partial evaluation of attributes, such as for example the weight sum. The process is founded in such a way that the decision-maker can clearly express his/her preferences, i.e. the levels of (un)desirability of the options, which are used for the evaluation of the variable. DEXi supports the methodology in a very intuitive and userfriendly way with a relatively wide range of choices for presenting the results of modeling and evaluation. This allows an interactive execution of the evaluation process steps without any difficulties.

The formation of the decisive model was based on the following phases: problem identification, criteria identification, definition of utility functions, and description of options, evaluation and analysis of the options.

\subsection{Problem identification}

The Faculty has not yet set up an information technology system to support the public relations. The article presents the decision model for the choice of the media in public relations in the case of the Faculty. The approach to the solution of the problem on the choice of the media for the execution of public relations in the article is based on multi-attributive decision making in expert systems.

The activities which have been completed in the field to date are the following: theoretical and comparative research of the problem; studies in the field of press alternatives; studies of the methods of communication appropriate for public relations; study of web pages of other faculties'; proposition for the internal model for web-based informing, the internet, brochures, activities at the beginning of the academic year.

The staff of the faculty's department and external members of the staff, who help to write and design the information, are the decision-makers, choosing the most appropriate medium to carry out the PR. With the best 
choice of the medium, they also aim to achieve one of the goals, set by the Faculty, i.e. its visibility on the national and the international level. Thereafter, the general goal of the decision process is the choice of the best media to carry out the public relations program. Given that many forms of media can be used to carry out the public relations program, the decision-maker can decide, on the basis of evaluation of the designed decision model, which media should be chosen as the main media and which as the support media. Numerical classification and with that the choice of the main and the support media is possible thanks to the quantitative display of the adequacy of the medium. The medium, which receives evaluation grade 5 after the evaluation, is chosen by the decision-maker to be the main medium; the media receiving lower grades are chosen to be the supporting ones. The media, which receive the lowest grade 1, are not to be chosen to carry out the public relations.

\subsection{Criteria Identification}

The model criteria, which need to be taken into consideration during the decision-making process, are listed in the Annex. They have been designed on the basis of the research of the literature on the subject of public relations and on the practical experience.

The literature (Rice \& Atkin, 2004; Kotler \& Armstrong, 2006; Theaker, 2004) states that the execution of public relations must be arranged according to the realistic goals the program aims to achieve, the public target must be determined, the message created, the dynamics of media appearances and the costs of the program must be determined as well.

In order to simplify the evaluation, the criteria are divided into three conceptual entities:

- the first group target contains recommendations, which deal with the identification of target publics and the recommendation of the medium through which the desired goals are to be achieved;

- the second group publication contains recommendations, which address the creation of the messages and the dynamics of media appearances;

- the third group price, contains the costs included in the press relations program.

The criteria, designed on the basis of the studies of Faculty's experience, are the ones dealing with the ability to reach target publics. Every 
organization has its target publics, which makes it reasonable to adjust the model in this part. This should not be problematic, since the authors took this into account during the construction of the model and therefore the conclusions could be generalized.

As already mentioned, the criteria were distributed into three basic entities: target, publication and price. These groups represent criteria derived from the multi-criteria model. The criteria target can take the value not achieved, partly achieved or entirely achieved. The criteria publication can be classified as unacceptable, acceptable or very acceptable. The criteria price can be evaluated under unacceptable, acceptable or very acceptable. With all the model criteria, the value is always increasing, which means that higher value is better than the lower one.

The first group of the aggregate criteria under the target category is composed of two aggregate criteria: availability and advisability. The constituent parts of the availability criterion are: internal public, external public and students. Identification of target publics is one of the main building blocks of public relations. In order to establish successful public relations, it must first be established towards whom the relations will be directed; whether it is possible to transmit information via the chosen medium; whether it is possible to adjust to local particularities; whether there is a possibility that its message will attract the existing and potential business partners, students and others. The Faculty's internal publics are the following: administration (the dean, the senate, the boards), pedagogical staff (i.e. lecturers, assistants, librarians and foreign experts), non-pedagogical staff (i.e. administration staff, researchers, receptionists). The Faculty's external publics are: state administration (chambers, associations, institutes, government agencies, other), the financial sources (donors, sponsors, bursary donors and others), the wider/general public (tax payers, radio, television, newspaper, magazine press, others). The students criterion comprises: undergraduate students (regular, part time, students with special needs and others), post-graduate students (the employed, unemployed), foreign students (international exchange students, others). The constituent parts of the advisability criterion are: communication with publics, preservation of communications and comprehension. Communication is the exchange of information between the organization and the public. Preservation is the keeping of the information from the other party. Comprehension is when the organization and the public share the same understanding of a problematic issue. 
The second group of the aggregate criteria, under the joint category publication, contains two aggregate criteria: the message and the execution. The building blocks of the message criterion are: the content of the message, the structure of the message and the form of the message. The message the organization transmits to the public must be the one which best fulfils the needs and the wishes of the public, the offer of the product to the service itself. During the formation of the message, four questions must constantly be answered, what to say, how to say it in a sensible way, how to produce a symbolic frame and who should transmit the message. The constituent parts of the execution criterion are: the scope of survey, the number of surveys and the frequency of appearances. Prior to the execution of public relations, the practitioner must find out what should the scope of survey be (in the local and the international market), what should the frequency of appearances be and what should be the quantity of surveys in a chosen medium. In the scope of survey, the practitioner should be considering whether the scope fulfils the needs of the organization, meaning she/he must find out whether a large enough part of the target public listens to, reads, watches etc. the medium executing public relations. The frequency of appearance considers how many times a day, a week etc. should the message appear in the media.

The third group of the aggregate criteria, joint under the price category comprises: the acquisition of media and the preparation of materials. The expenses of media acquisition include banquets, organized to attract the media, by showing oneself in a positive light. The expenses of the preparation of materials include fee for the publicity creators, payment of technical expenses and fee for the occurring intellectual property rights.

On the basis of the identified criteria, a tree of criteria has been designed to evaluate the adequacy of media for the execution of public relations (see Annex). The criteria tree clearly shows the relation between the defined basic and aggregate criteria (in bold print), i.e. the hierarchy of criteria. The basic criteria are pictured as the leaves of the decision tree.

\subsection{Definition of utility}

Beside the criteria, the knowledge base is also determined by the utility function $\left(F_{i}\right)$, for all the aggregate criteria down to the roots of the tree, which is the final evaluation of options. These are the rules of decision making in the nodes of the tree, which determine the value of each criterion, with the exception of leaves of the tree. On the basis of mutual 
dependence of bottom placed criteria, the aggregation function determines the value of the aggregated attribute (Bohanec \& Rajkovič, 1999). The utility function must be substantially adequate; it must namely assign greater value to the better option.

\section{Figure 2: Example of the utility function for the evaluation of medium adequacy aggregate criterion}

\begin{tabular}{llll} 
Goals & Publication & Price & Evaluation on medium adequancy \\
\hline $59 \%$ & $24 \%$ & $17 \%$ & \\
\hline 1 not achieved & $*$ & $*$ & 1 \\
2 <=partly achieved & unacceptable & unacceptable & 1 \\
\hline 3 partly achieved & unacceptable & $>=$ acceptable & 2 \\
4 entirely achived & unacceptable & unacceptable & 2 \\
\hline 5 partly achieved & acceptable & <=acceptable & 3 \\
6 partly achieved & $>=$ acceptable & unacceptable & 3 \\
7 >=partly achieved & acceptable & unacceptable & 3 \\
8 entirely achived & unacceptable & acceptable & 3 \\
\hline 9 partly achieved & $>=$ acceptable & very acceptable 4 \\
10 partly achieved & entirely acceptable & >=acceptable & 4 \\
11 entirely achived & unacceptable & very acceptable 4 \\
12 entirely achived & entirely acceptable unacceptable & 4 \\
\hline 13 entirely achived & $>=$ acceptable & >=acceptable & 5 \\
\hline
\end{tabular}

Figure 2 shows the aggregate criterion of the evaluation of medium adequacy evaluated with the grade 1, if the criterion target reaches the lowest stock of value (not achieved), regardless of the value the criteria publication and price managed to achieve. The evaluation of the medium adequacy is evaluated as 1, if the criterium target reaches the values, lower than that of partly achieved, while the criteria publication and price reach the lowest value (bad or unacceptable). The adequacy of medium is evaluated with grade 5, if the criteria target scores the highest value, i.e. entirely achieved, where criteria, publication and price must achieve at least the good or acceptable targets, i.e. the medium or maximum value.

Figure 2 also clearly shows, how the target criterion is the most important, i.e. scores the highest in the evaluation $(58,70 \%)$, followed by the criterion publication, which influences the evaluation in the proportion of 23,91\%, the last criterion being the price, which influences the evaluation in the share of $17,39 \%$ of the overall evaluation. The stocks of value are determined by the practitioner, in our case a public relations officer, on the basis of knowledge, acquired information, experience or by following his/her intuition. 


\subsection{Description of options}

The media via which the organizations can perform public relations are: radio, television, newspapers, magazines, billboards, and the internet, flyers, and public events, events for smaller groups of people, announcements and other. Each medium has its general features, advantages and weak points.

The described model allows the choice of media. After choosing the media, the actual media transmitters must also be chosen which cannot be done with the help of the model, so this decision is therefore for the practitioner to make. In this case her/his choice is based on the price and the exclusivity of the individual product. A new model should be established for the decision on actual medium transmitters. All the transmitters within the individual medium should be considered for the establishment of a new tree.

In our case the chosen options were: the internet, events, press conferences, publications and press releases, because these are the most appropriate media.

The Internet represents the internal information network, which allows quicker and fuller flow of information and more rational, faster and more efficient business. It easily displays an integrated collection of updated information and allows efficient feed-back; it unites color, picture, sound, movement, it makes it easy to reach a large population; the expenses are not high and longer period of exposure is possible.

The performance of events for a larger number of people includes planning, concept, organization, management, execution of the key communication tool, their main goal is to offer a situation where people meet. The goals of the organization can only be achieved, if the desired target public participates at the events. The events organized by the Faculty for its target public are: social events, anniversaries, expert excursions, presentations, annual staff meetings, opening lectures, seminars, initiation parties for first year students, etc.

Events for smaller groups of people are similar to meetings, at their occasion public relations officers release their message via television, radio or press media.

The publications, published by the Faculty are presentation brochures in Slovene and foreign languages, annual business reports, information 
materials about the structure of the Faculty, newsletters, magazines and other. With publications it is possible to reach a large number of the population, to gain trust. Publications have no time limits, a personal approach towards the chosen publics is possible, so are quality reproduction, long life expectancy, transition among target publics etc. The downside of publications is the possibility for potential misinterpretations, high cost and other.

\subsection{Discussion on evaluation and analysis of options}

Each of the above mentioned options is appropriate for the execution of the Faculty's public relations. Use of the decision model enables us to choose the basic media and to make a list of support media according to their utility.

In order to achieve this, we must find out whether it is possible to transmit the message through the chosen media to the chosen public; whether the scope of appearances fulfils the needs of organization; whether it is possible to achieve a high frequency of repetition; is it possible to adjust the message to local specifications; how many times can the released messages be detected; what are the costs, etc. The media works similar to the human brain, when a term becomes well established in the media, it is difficult to modify it, and the choice of the appropriate media is therefore a crucial one.

The evaluation, which is carried out in the designed decision model, takes shape as the public relations practitioner evaluates the chosen options on the basis of all criteria determined in the model. Determined stocks of value of all the basic and the aggregate criteria and their decision rules i.e. functions of utility, all influence the final evaluation of the option (the percentage of the importance of the basic criterion within the derived criterion). The best option is the one which scores the highest final grade on the evaluation of the media adequacy.

At the end of the article, there is a table of the results of the evaluation. The final evaluation could also be determined, if the evaluations of the options would not contain the evaluations of all possible criteria, meaning that the options could take any other value. In such case, there would be intermediate evaluations. In order to avoid them in the testing of the model, all the options were evaluated according to all the criteria. In this case, the term intermediate evaluation means the final evaluation of 
the media adequacy is between two evaluations. If we take the example of an event for a smaller number of people: in our case the evaluation is 1, but if some of the criteria would take whichever value, the final evaluation would be between 1 and 2, and it would appear in the table as 1:2.

If we compare the results of the evaluation of individual options, we can see that the highest value for the adequacy of the execution of public relations, evaluation 5, goes to the internet, and the lowest, evaluation 1, goes to an event for a smaller number of people. The results of the evaluation allow us to conclude, that the most adequate public relations media is the internet, followed by publication and an event for a larger number of people.

The DEXi software system shows the representation of the evaluation results in individual criteria. Figures 3 to 6 show the results of the evaluation criteria: goal, price, execution, message, advisability, availability, on the basis of which the model analysis were performed.

On the basis of the evaluation of individual criteria, it was found out, that the option publication has better evaluation of the criterion message and lower evaluation of the criterion advisability than the variable event for a larger number of people. Because the message criterion has greater influence onto the final evaluation than the advisability criterion, the final evaluation of the publication variable is higher. The variable internet is the variable with the best evaluation according to all the stated criteria.

Figure 3: Results of evaluation based on individual criteria for the publications

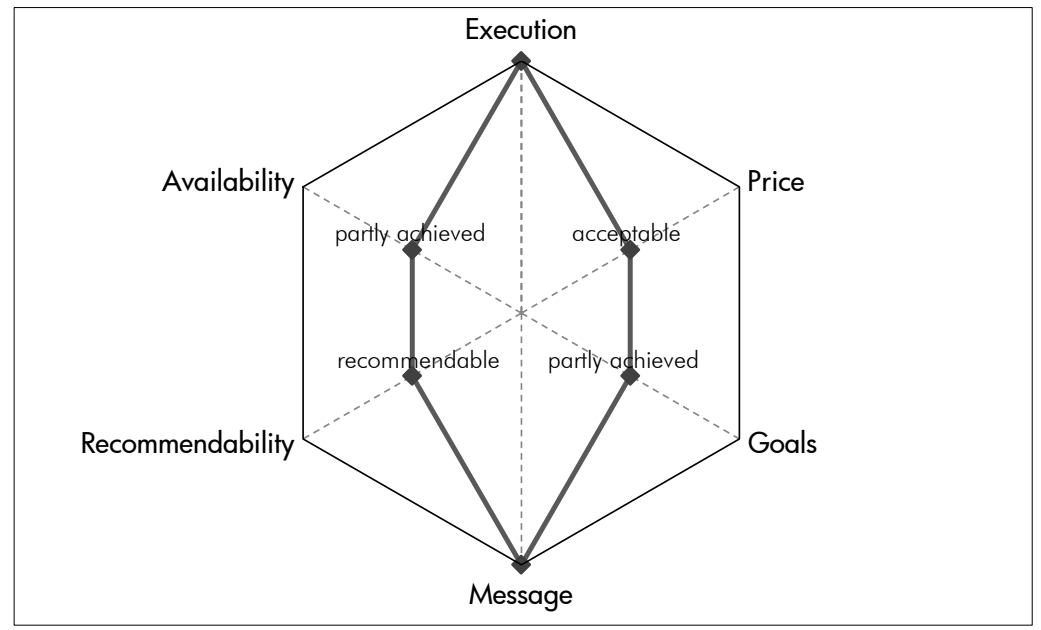


Figure 4: Results of evaluation based on individual criteria for the events for smaller groups of people

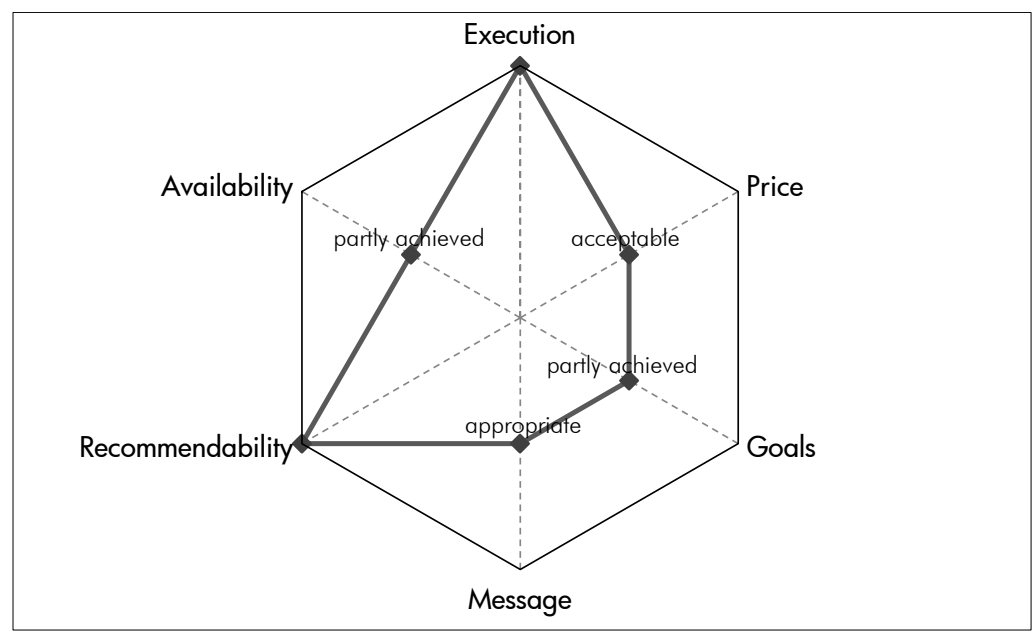

Figure 5: Results of evaluation based on individual criteria for the internet

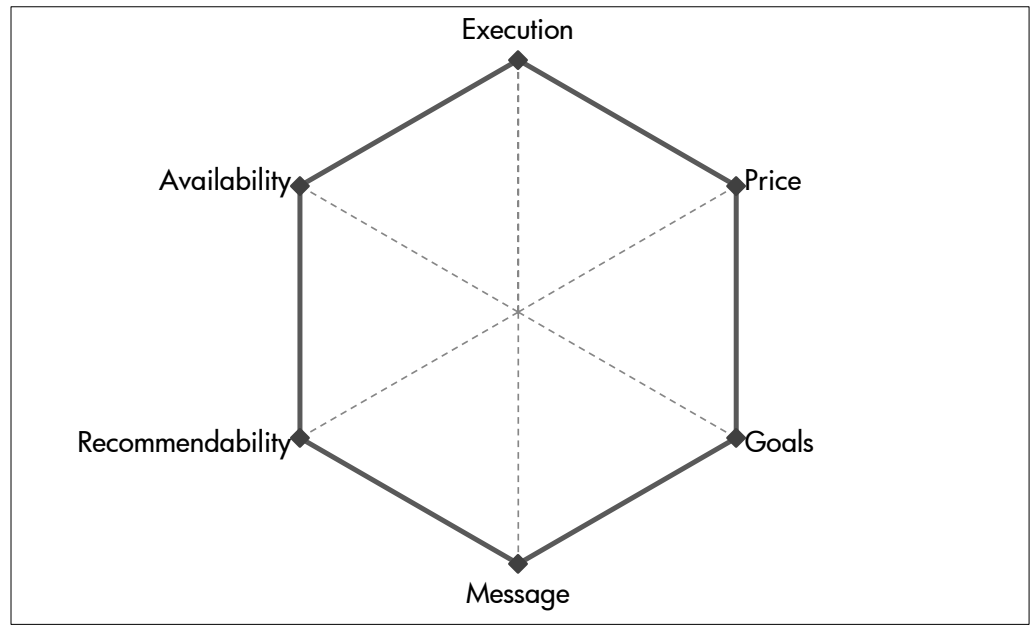

On the basis of the results of the evaluation and their analysis, the chosen medium for the press relations is the internet. If we predict that the twoway symmetric model, as envisaged by Gruning (Hunt \& Gruning, 1994), truly is the most successful press relations model, than we can conclude, that our evaluation is correct. The option allows the management of press relations, offering a dialogue between the organization and the publics (i.e. surveys on the Faculty's webpage) to allow mutual adjustments and mutual benefits. 


\section{Figure 6: Results of evaluation based on individual criteria for the events for larger number of people}

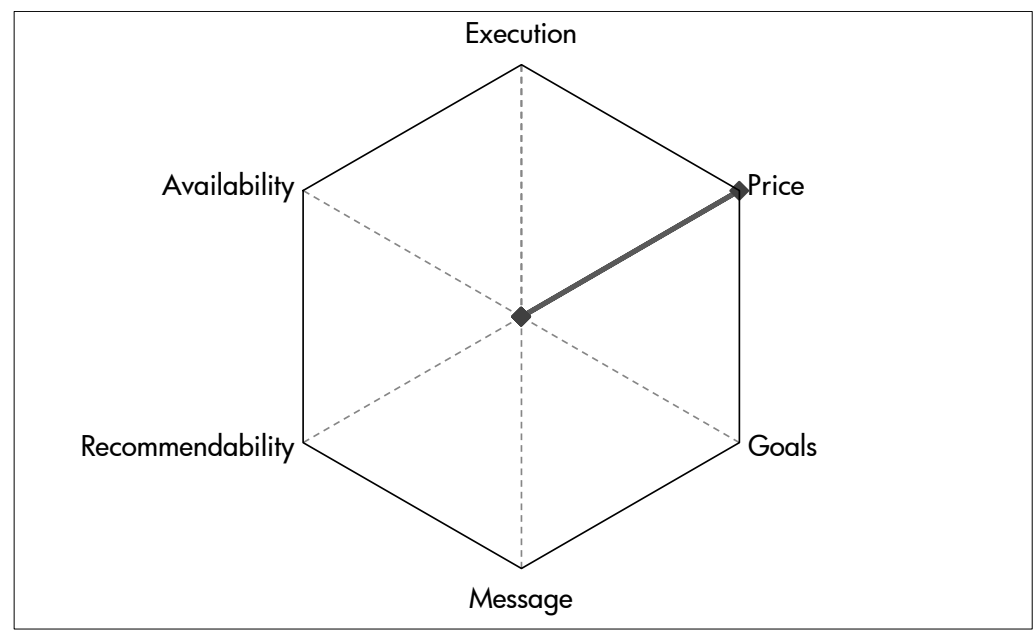

\section{Conclusions}

Organizations communicate within themselves and also with others in the environment because they do not exist in isolation. Thus they communicate with communities, governments, customers, financial institutions and others that have relationships with them. It is crucial for the public relations that the organization management participates which means that the goals of public relations must be precisely defined, together with actual tasks, careful planning of activities, an organizational structure which allows the achievement of goals. The control functions must also be set up, the results must be evaluated. The same goes for content, methods and the dynamics of the performance, which should be adjusted to the given circumstances.

The article presents the decision model for the choice of the media in public relations in the case of the Faculty. The approach to the solution of the problem on the choice of the media for the execution of public relations in the article is based on multi-attributive decision making in expert systems. The basic principle of the multi-attribute decision making methods is the decomposition of the decision problem onto smaller, less complex problems, which allow transparency and comprehension of the decision problem, and simultaneously allow reception of a quality and 
explainable decision. The model is designed with the support of the DEXi system.

The decision can be made without the support of the system, but the model allows easier decision making, especially when a large number of criteria, options and complex decision-making rules, which are all included in the designed model, must be taken into consideration before the decision is made. Before the execution of the press relations program and simultaneously the choice of the medium, there is a need for a careful study of the target groups, for the design of the message and last, but not least, the amount of expenses needs to be calculated. The recommendations stated here are designed into the aggregate model criteria. The model calls for the decision maker's knowledge of the positive and negative features of the medium, which represents the decision making options within the model.

The model is a helpful tool for the support of decision making in the case of demanding decisive situations, which are based on a large number of influential factors of the variables (the article presents the choice of four variables). The model is an important contribution to a more systematic and quality decision-making; it can however not substitute a human decision-maker, responsible for the final decision.

In the design of the decisive model and the determination of decisie rules for the derived criteria, the knowledge on the subject of decision making is called for, similarly, there is a need for specific knowledge to construct hierarchy of the decision tree on the basis of links in the content of the criteria and the determination of reasonable value stock and the derived criteria.

The use of experimental system methods allows the transparency of the model and explains the decisive knowledge and the decision itself. It is the management of the decisive knowledge with the help of modern methods of artificial intelligence, which lead to defined and widely comprehensible decisions, diminishing the possibility of bad, i.e. incorrect decision. The model directs the decision maker into thinking, information gathering on the problem of the choice of the media and minimizes the ignorance of factors, which influence the final decision. The model, based on the evaluation of a number of influential criteria, cuts the danger of making the wrong decision, the cost and the risks occurring when the decision is being made. 
The main advantages of the model are the following: The explanation of the final evaluation is possible (explanation on how each individual evaluation was acquired according to the value of the criteria and of the applied decision-making rules), so are the "what-if" analysis, performed with the change of options descriptions, their second evaluation and the comparison of thus acquired results with initial results and the selective explanation of options. The decision-making process is transparent, with table and graphic presentations of the evaluation and of the entire process of the method. Model allows rational decision making, based on decision-finding, results analysis and decision evaluations. It also allows further improvements. The model is not currently used in practice; it is designed so that the Faculty can use it in practice.

\section{Annex}

\section{Figure 7: Tree of the criteria for the evaluation of adequacy of the media for the execution of public relations}

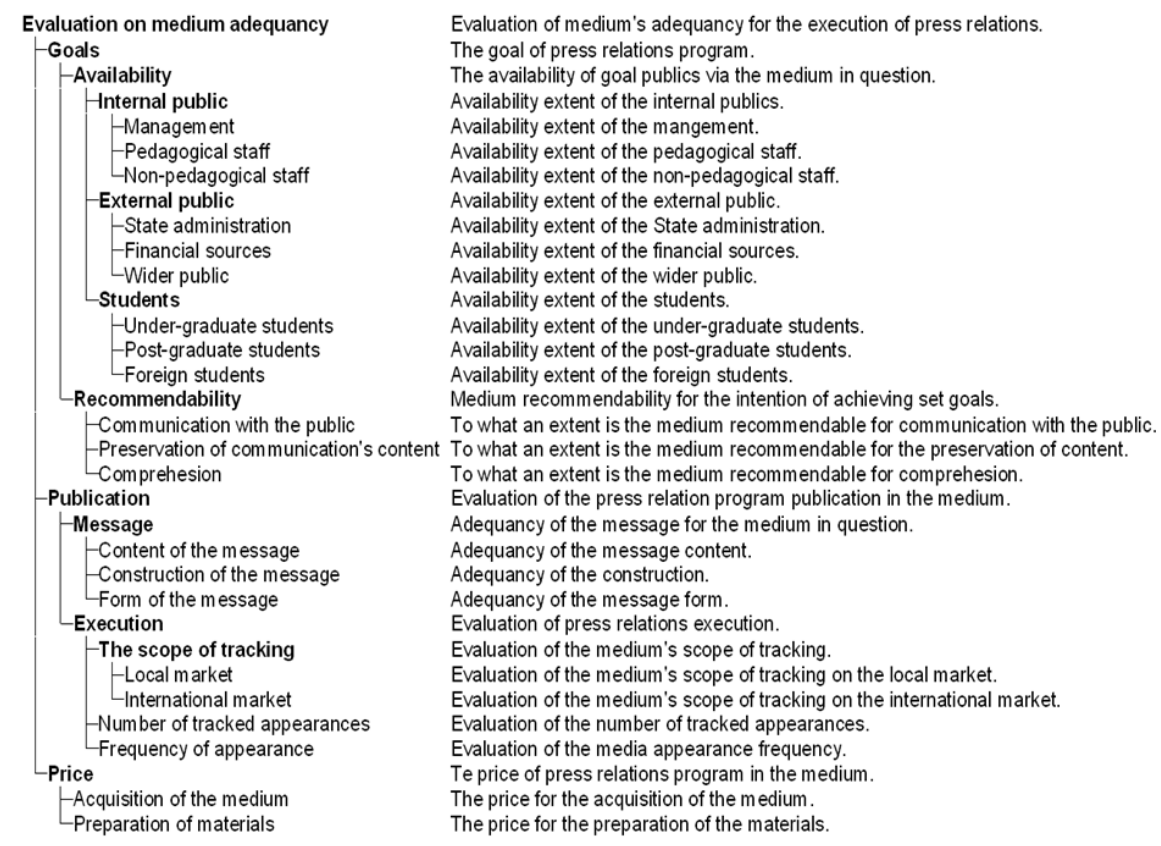


Mag. Tatjana Kozjek workes at the Faculty of Administration, University of Liubliana as an assistant in the field of public sector organizations. She explores and examines the scope of public sector organizations and human resource management; participates in internal and external projects, the preparation and execution of exercises for students and seminars for civil servants.

Dr. Vladislav Rajkovič is a professor emeritus of information system at University of Maribor, Faculty of Organizational Sciences, and a senior researcher at the Intelligent Systems Department at Jožef Stefan Institute. His research interests focus on information systems and artificial intelligence methods for supporting decision processes and education.

Dr. Marko Ferian is a full professor at the University of Maribor's Faculty of Organizational Sciences. He received his master's degree and doctorate at the University of Maribor. The topic of his master's thesis was business communication, and his doctoral dissertation addressed educational planning. His articles have appeared in Slovenia and abroad, and he has published research in the Journal of Economics (ISSN 0013 3035). He has authored a number of books on business communication and educational planning, with his latest book appearing in October 2005. His very first book Skrivnosti vodenja šole $k$ znanju, uspehu in ugledu (The Secrets of Leading a School towards Knowledge, Success and Reputation, 1996) met with an International response and was reviewed in the International Journal of Lifelong Education (vol. 16, no. 4). 


\section{References}

- Anderson, N. \& Goltsi, V. (2006). Negative Psychological Effects of Selection Methods: Construct Formulation and an Empirical Investigation into an Assessment Center. International Journal of Selection and Assessment (14), 236-255.

- Bohanec, M. \& Rajkovič, V. (1999). Multi-Attribute Decision Modeling: Industrial Applications of DEX. Informatica (23), 487-491.

- Bohanec, M., Zupan, B. and Rajkovic, V. (2000). Applications of qualitative multi-attribute decision models of health care. International Journal of Medical Informatics (58-59), 191-205.

- Chankong, V. \& Haimes, Y. Y. (1983). Multiobjective Decision Making: Theory and Methodology. North-Holland.

- Hunt, T. \& Gruning, J. E. (1994). Public relations techniques. Fort Worth: Harcourt Brace College Publishers.

- Jereb, E., Rajkovič, U. \& Rajkovič, V. (2005). A Hierarchical Multi-Attribute System Approach to Personnel Selection. International Journal of Selection and Assessment (3), 198-205.

- Kitchen, P. (1997). Public Relations, Principles and Practice. International Thomson Bussiness Press.

- Klein, M. and Methlie, B. L. (1995). Expert Systems: A Decision Support Approach with Application in Management and Finance. Old Tappan, NJ: Addison-Wesley.

- Kotler, P. (2003). Marketing Management, Eleventh Edition. Upper Saddle River (New Yersey): Pearson Education International, London.

- Kotler, P. \& Armstrong, G. (2006). Principles of Marketing, European Edition. London: Prentice Hall Europe, Simon \& Schuster International.

- Mallach, E. G. (2000). Decision Support and Data Warehouse Systems. New York: McGraw-Hill.

- Rajkovič, V., Šušteršič, O., Šušteršič, J. \& Bohanec, M. (1999) How to Increase the Quality of Health and Education Sectors? Blve paper, Civil society in Slovenia and Europe. Ljubliana: The Municipality Forum Association, The government office for EU affairs.

- Rice, R. E. \& Atkin, C.K. (2001). Public Communication Campaigns, Third Edition. Thousand Oaks: Sage Publication, Inc.

- Splichal, S. (1999). Public Opinion: Developments and Controversies in the Twentieth Century. Oxford: Rowman \& Littlefield Publishers Inc.

- Tedlow, R. (1979). Keeping the Corporate Image, Public Relations and Business, 1900-1950. Greenwich, CT: JAI Press.

- Theaker, A. (2004). The Public Relations Handbook. New York, London: Routlege.

- (17) Triantaphyllou, E. (2000). Multi-Criteria Decision Making Methods: A Comparative Study. Kluwer Academic Publishers.

- (18) Wilcox, D. L., Ault, P. M. \& Agee, W. K. (1992). Public Relations Strategies and Tactics. Harper Collins. 
POVZETEK

\section{ODLOČITVENI MODEL ZA IZBIRO MEDIJA PRI IZVAJANJU ODNOSOV Z JAVNOSTMI}

Kliučne besede: odnosi z javnostmi, informacijska tehnologija, večparametrsko odločanje, odločitveni model, DEXi

Komunikacijski proces predstavlja enega pomembnejših procesov človekovega sodelovanja in ustvarjanja. Komuniciranje je $v$ vsakdanjem družbenem in gospodarskem življenju izredno pomembno in nepogrešljivo. Brez komunikacii ne more delovati nobena organizacija, saj imajo velik vpliv na odnose med vsemi, ki v organizaciii stremijo $k$ obvladovanju delovnega procesa in doseganju skupnih ciljev. Pozornost je treba nameniti tudi odnosom z javnostmi. Vse dejavnosti odnosov z javnostmi je treba načrtovati, upravljati in vrednotiti. Zlasti pomembno je načrtovanje, iz katerega sledi izvajanje. Za odnose z javnostmi je bistveno, da so vključeni $v$ menedžment organizacije. To pomeni, da morajo biti natančno opredeljeni cilji odnosov z javnostmi; konkretne naloge; skrbno planirane dejavnosti; vzpostavljena taka organizacijska struktura, ki omogoča doseči cilje; izvajati je treba kontrolno funkcijo; vrednotiti rezultate; vsebino, metode ter dinamiko izvajanja po potrebi prilagajati konkretnim okoliščinam. Odnosi z javnostmi se lahko uporabliajo kot pomoč pri povečanju prepoznavnosti produktov, ljudi, krajev, idej, aktivnosti, organizacii in tudi narodov (Kotler \& Armstrong, 2006). Nijhovo osnovno ogrodje so komunikacije (Hunt \& Gruning, 1994), bistro pa je v odločanju.

Odločanje je običajno del splošnega reševanja problemov in nastopa kot pomembna mentalna aktivnost na praktično vseh področjih človekovega delovanja. Težavnost odločitvenih problemov je zelo raznolika. Sega od enostarnih osebnih odločitev, ki so večinoma rutinske in se jih velikokrat niti ne zavedamo, vse do težkih problemov skupinskega odločanja, na primer pri vodenju, upravljanju in planiranju $\vee$ podjetjih, kadrovskem odločanju, medicinski diagnostiki in vrsti drugih področij. Najpomembnejši problemi, ki nastopajo pri odločanju o izboru medijev v primeru, ki ga obravnava prispevek, izvirajo iz: velikega števila dejavnikov, ki vplivajo na odločitev; številnih oziroma slabo definiranih ali poznanih variant; zahtevnega prepoznavanja odločitvenega problema in ciljev odločitve. 
$\checkmark$ podporo pri odločanju je bilo razvitih tudi mnogo metod in računalniških programov za podporo odločanja (angl. Decision Support Systems (DSS)). Metode večparametrskega odločanja (angl. MultiAttribute Decision Making) so po eni strani dobro teoretično osnovane v okviru odločitvene teorije in teorije koristnosti, po drugi strani pa se uspešno uporabljajo $\vee$ praksi pri podpori zahtevnih odločitvenih problemov. Teorija večkriterijskega odločanja nudi formalno osnovo izgradnji modela, kjer je ključni kriterii povezovanje ocen po posameznih parametrih v celostno oceno (Bohanec \& Rajkovič, 1999; Chankong \& Haimes, 1983; Klein \& Methlie, 1995). Variante je treba razgraditi na posamezne parametre (kriterije, atribute) in jih ločeno oceniti glede na vsak parameter. Oceno variante se dobi s postopkom združevanja, tako izpeljana vrednost je potem osnova za izbor najustreznejše variante (Rajkovič et al., 1999).

Rajkovič in drugi (1999) ločijo naslednje elemente odločitvenega procesa: (množico variant $A: a_{1}, a_{2}, a_{3}, \ldots, a_{m}, \ldots$; preferenčno relacijo $P$, ki uredi množico A po zaželenosti, ustreznosti oziroma koristnosti, pri čemer a P b pomeni, da imamo varianto a rajši kot varianto b; funkcijo koristnosti v(a), ki izmeri stopnjo zaželenosti variante a tako, da za vsak par a, b iz A velja: $a P b \leftrightarrow v(a)>v(b)$; racionalno odločitev, ki pomeni izbiro tiste variante $a_{i}$ iz $A$, ki je najboli zaželena: $v\left(a_{i}\right)=\max (v(a): a \in A)$. Pri večparametrskem odločanju pa imamo množico parametrov $X: x_{1}, x_{2}, \ldots, x n$, pri čemer je $x_{i}: A \rightarrow D_{i}$, kjer so $D_{i}$ zaloge vrednosti i-tega parametra. Variante opišemo z naborom (vektorjem) vrednosti v*: $D_{1} \times D_{2} X \ldots X D_{n} \rightarrow D$. Funkcijo koristnosti v: $A \rightarrow D$ nadomestimo $z v^{*}: D_{1} \times D_{2} X \ldots X D_{n} \rightarrow D$, pri čemer predpostavimo: $v\left(a_{i}\right)=v^{*}\left(x_{1}(a), x_{2}(a), x_{3}(a), \ldots, x_{n}(a)\right)$. Funkcija koristnosti predstavlja združeno meritev koristnosti po vseh parametrih. Je kriterijska funkcija, s katero določimo koristnost variant na osnovi kriterijev in njihovih povezav.

Večparametrski odločitveni model je tako $v$ splošnem sestavljen iz dveh tipov komponent: atributov $\left(\mathrm{x}_{\mathrm{i}}\right)$ in funkcii koristnosti $\left(\mathrm{F}_{\mathrm{i}}\right)$. Atributi, imenovani tudi parametri ali kriteriii, so spremenljivke, ki ponazarjajo podprobleme odločitvenega problema. Urejeni so $v$ hierarhično strukturo, ki ponazarja medsebojne odvisnosti med atributi: višjenivojski atributi so odvisni od neposrednih naslednikov. Glede na položaj ločimo atribute na osnovne (končna vozlišča - listi) in izpeljane (notranja vozlišča). V modelu je za vsak izpeljani atribut določena funkcija koristnosti F, ki opredeljuje odvisnost tega atributa od neposrednih naslednikov $v$ strukturi. Variante 
opišemo z vrednostmi osnovnih atributov (ai). Vrednotenje variant poteka "od spodaj navzgor", to je s postopnim združevanjem vrednosti v skladu s strukturo modela in funkcijami koristnosti (Bohanec et al., 2000; Bohanec \& Rajkovič, 1999).

$\checkmark$ prispevku je prikazan odločitveni model za izbiro medijev pri izvajanju odnosov z javnostmi. Novost modela je $v$ uporabi sodobne informacijske tehnologije, s posebnim poudarkom na metodah umetne inteligence $v$ postopkih odločanja, ki omogočajo transparentnost in razlago odločitvenega znanja in odločitve same. $V$ okviru rešitve je opisana realizacija modela s pomočjo programskega sistema DEXi. Model upošteva tako kvantitativna kot kvalitativna merila izbora. S tem je dosežena celovitejša slika o medijih in ciljih, ki se jih želi z odločitvijo doseči. Opredelieni so temeljni elementi modela, kot so: ciljna javnost; cilji, ki jih želi organizacija doseči z odnosi z javnostmi; sredstva, namenjena odnosom z javnostmi; sporočila, ki jih želimo posredovati javnostim; in drugo. Kriteriji, ki so sestavni del odločitvenega modela, so bili oblikovani na podlagi proučevanja literature s področja odnosov z javnostmi in praktičnih izkušenj na fakulteti.

Odločitveni model je podlaga za sprejem konkretne odločitve za izbor medijev, preko katerih fakulteta izvaja odnose z javnostmi. Delovna hipoteza, ki je bila pred oblikovanjem modela postavljena, je: z ustrezno tehnologijo za upravljanje znanja je mogoče oblikovati večkriterijski odločitveni model za izbiro medija pri izvajanju odnosov z javnostmi v konkretni organizaciji. Cili je bil torej oblikovanje modela z upoštevanjem tako kvalitativnih kot kvantitativnih meril izbora, ki bi dala jasen vpogled na problem izbire medijev pri izvajanju odnosov z javnostmi. Kvalitativna merila izbora so ( $v$ zalogah vrednosti) upoštevana pri kriterijih cilii, objava in cena, kvantitativna merila izbora pa pri kriteriju ocena primernosti medija, saj zaloga vrednosti zavzema kvantitativne vrednosti. Pristop $k$ rešitvi problema izbire medijev za izvajanje odnosov z javnostmi, opisanem $v$ članku, temelii na večkriterijskem odločanju in ekspertnih sistemih. Osnovni princip metod večkriterijskega odločanja je razgradnja odločitvenega problema na manjše, mani kompleksne probleme, kar omogoča transparentnost ter razumevanje odločitvenega problema, hkrati pa sprejem kakovostnejše in razložljive odločitve (Bohanec \& Rajkovič, 1999; Klein \& Methlie, 1995). 
Oblikovanje odločitvenega modela je sledilo naslednjim fazam: identifikacija problema, identifikacija kriterijev, definicija funkcii koristnosti, opis variant ter vrednotenje in analiza variant. Vsaka izmed variant je primerna za izvajanje odnosov z javnostmi na fakulteti. Uporaba odločitvenega modela pa omogoča izbrati osnovni medij ter po primernosti razvrstiti podporne medije. Da bi lahko to dosegli, je treba ugotoviti, ali je preko konkretnega medija mogoče posredovati sporočilo želeni ciljni javnosti; ali obseg spremljanja zadosti potrebam organizacije; ali je možno doseči visoko frekvenco ponavljanja; ali je možno sporočilo prilagajati lokalnim posebnostim; kolikokrat je možno spremljati oddano sporočilo; kolikšna je cena in drugo. Mediii namreč delujejo tako kot človeški možgani, ko se neki izraz $v$ medijih uveljavi, ga je težko spremeniti, zato je izrednega pomena, da je izbor medijev pravilen.

Vrednotenje poteka $v$ oblikovanem odločitvenem modelu tako, da praktik odnosov z javnostmi izbrane variante oceni na podlagi vseh kriterijev, ki so določeni $v$ modelu. Na končno oceno variante vplivajo določene zaloge vrednosti vseh osnovnih in izpeljanih kriterijev ter njihova odločitvena pravila oziroma funkcije koristnosti (odstotek pomembnosti osnovnega kriterija znotraj izpeljanega kriterija). Najboliša je tista varianta, ki ima končno najvišjo oceno primernosti medija.

Samo odločanje sicer lahko poteka tudi brez sistema za podporo odločanja, model pa omogoča lažje odločanje, sai je pred odločitvijo treba paziti na vrsto kriterijev, variant in zapletena odločitvena pravila, ki so upoštevana $v$ oblikovnem modelu. Pred izvedbo programa odnosov $z$ javnostmi in s tem izborom medija je treba skrbno proučiti ciljne javnosti, cilje, oblikovati sporočilo ter vedeti, koliko sredstev se lahko porabi. Omenjena priporočila so oblikovana $v$ izpeljane kriterije modela. Model od odločevalca zahteva poznavanje pozitivnih in negativnih lastnosti posameznih medijev, ki v modelu predstavljajo variante odločanja. Model tako pomembno prispeva $k$ bolj sistematičnemu in kakovostnemu odločanju, vendar ni nadomestilo za človeka, ki je odgovoren za sprejeto končno odločitev. Rezultati vrednotenja praktikom omogočajo tudi razlago sprejetih odločitev. Model, ki temelji na vrednotenju več vplivnih kriterijev, tako zmanjša nevarnost sprejema nepravilne odločitve in $s$ tem tudi stroškov in tveganja, ki nastanejo ob njenem sprejemu. Bistvene prednosti modela so: omogočena je razlaga končne ocene (razloži, kako je bila vsaka posamezna ocena pridobliena glede na vrednosti kriterijev in uporabljenih odločitvenih pravil) ter analiza tipa "kaj-če", ki je izvedena s 
spremembo opisa opcij, njihove ponovne ocenitve in primerjave dobljenih rezultatov s prvotnimi rezultati ter selektivna razlaga opcij. Sam odločitveni postopek je pregleden, saj so tabelarno in grafično prikazani rezultati ocenjevanja in celotnega poteka postopka. Model omogoča racionalno odločanje, ki temelii na snovanju odločitev, analizi rezultatov ter ocenjevanju odločitev. 